\title{
Pola, Prinsip, dan Tugas Supervisi PAI
}

\author{
Andi Fadhilah A.Natsir \\ Universitas Muslim Indonesia \\ afadhilah27@gmail.com
}

\begin{abstract}
Abstrak
Dalam dunia pendidikan dikenal adanya pengawas satuan pendidikan yang memiliki tugas tertentu dalam mengawasi jalannya pendidikan. Pengawas satuan pendidikan itu disebut sebagai supervisor. Seorang supervisor bertindak atas dasar ketentuan-ketentuan yang bersifat ilmiah dalam melaksanakan tugasnya agar dapat meningkatkan mutu dan kualitas pendidikan. Supervisor harus mempunyai suatu kompetensi khusus yang dapat melihat permasalahan dalam pendidikan yang sedang terjadi. Sebagai seorang supervisor sangat penting untuk mengetahui apa saja pola-pola supervisi yang tepat digunakan seperti supervisi umum, supervisi PBM dan supervisi kolegial atau kelompok. Selain itu dalam menjalankan tugas sebagai seorang supervisor, prinsip-prinsip supervisi harus diterapkan dengan baik sehingga proses pendidikan dapat berjalan sebagaimana mestinya dan tujuan pendidikan dapat dicapai. Adapun tugas-tugas supervise PAI adalah dimulai dari menghadiri rapat/pertemuan dengan guru-guru PAI, mendiskusikan masalah dan metode-metode mengajar guru khususnya dalam PAI, memberikan pembinaan, demonstrasi mengajar, mengevaluasi, dan memberikan penilaian.
\end{abstract}

Kata Kunci: Pola, Prinsip, Tugas Supervisi, Pendidikan Agama Islam

\section{Pendahuluan}

Pendidikan adalah usaha yang dilakukan secara sadar dan sengaja untuk mencapai tujuan yang telah dicita-citakan. Secara umum, pendidikan bertujuan untuk meningkatkan mutu sumber daya manusia secara menyeluruh. Pendidikan juga diharapkan mampu menghasilkan karakter manusia yang dapat memahami dan mampu membangun tatanan hidup masyarakat di sekitarnya. Dengan demikian tujuan ataupun proses pendidikan hendaknya disesuaikan dengan kebutuhan, keadaan serta yang ada dalam masyarakat.

Dalam dunia pendidikan dikenal adanya pengawas satuan pendidikan yang memiliki tugas tertentu dalam mengawasi jalannya pendidikan. Seorang supervisor bertindak atas dasar ketentuan-ketentuan yang bersifat ilmiah dalam melaksanakan tugasnya agar dapat meningkatkan mutu dan kualitas pendidikan.

Salah unsur dalam pendidikan yang membutuhkan pelayanan supervisi adalah guru. Bantuan supervisi pendidikan terhadap guru dianggap sangat penting dalam kehidupan masyarakat karena guru yang baik akan menghasilkan generasi yang baik pula.

Seorang supervisor harus mengetahui dan memahami dengan baik pola-pola, prinsip serta tugasnya sebagai supervisor, dengan demikian mutu pendidikan dapat meningkat.

\section{Rumusan Masalah}

Adapun rumusan masalah dari latar belakang yang dikemukakan di atas ialah:

a. Bagaimana pola supervisi Pendidikan PAI ?

b. Bagaimana prinsip-prinsip supervisi pendidikan PAI ?

c. Bagaimana tugas-tugas pengawas supervisi PAI ? 


\section{Pembahasan}

\section{a. Pola supervisi}

1) Supervisi Pendidikan/Umum

Cangkupan secara umum supervisi pendidikan sangatlah luas. Dimulai dengan hal-hal yang berkaitan di dalam kelas sampai yang berkaitan dengan hal-hal di luar kelas.

Supervisi pendidikan merupakan kegiatan pembinaan yang dilakukan dalam rangka memperbaiki situasi pendidikan agar dapat menghasilkan pendidikan yang berkualitas.

Sehingga dapat dikatakan bahwa supervisi ini lebih menekankan pada perbaikan situasi pendidikan, bukan pada perbaikan pengajaran. Perbaikan situasi pendidikan yang dilakukan meliputi pembinaan terhadap orang-orang yang berperan di sekolah yaitu guru-guru dan segala hal yang berkaitan dengan pengembangan pendidikan termasuk kurikulum ataupun fasilitas yang digunakan dalam pembelajaran di sekolah, pemanfaatan bangunan, pengelolaan admisnistrasi, keuangan, dan sebagainya dengan tujuan untuk meningkatkan kualitas pendidikan.

Dengan adanya supervisi umum, diharapkan guru akan merasa terbantu dalam memecahkan masalah-masalah dalam situasi pendidikan bukan sebaliknya merasa tertekan agar semua pihak dapat bekerja sama secara professional sehingga tujuan supervisi dapat tercapai dengan baik.

\section{2) Supervisi Klinis/PBM}

Berbeda dengan supervisi umum, supervisi ini bertujuan untuk memperbaiki pengajaran. Jadi, fokus utamanya adalah pelaksanaan kegiatan belajar mengajar atau PBM yang terjadi di kelas sehingga supervisi ini bisa juga disebut supervisi kelas.

Menurut John J.Bola dalam Ngalim Purwanto, supervisi klinis ialah proses membantu guru mengurangi kesenjangan antara perilaku mengajar yang nyata dengan suatu proses pembinaan yang tujuannya untuk membantu mengembangkan profesionalitas guru/calon guru terlebih pada penampilan pengajaran, sesuai dengan tinjauan dan analisis data secara seksama dan objektif sebagai pedoman dalam perubahan perilaku mengajar.

Supervisi klinis membantu guru dalam memperbaiki dan mengembangkan profesionalitas dirinya dalam menyajikan bahan ajar.

Sistem kerja dari supervisi klinis dimulai dengan dilakukannya observasi dalam proses pembelajaran di kelas, kemudian selanjutnya yaitu menganalisis masalah atau hal-hal apa saja yang menjadi penghambat bagi siswa dalam memahami materi ajar yang telah disajikan. Setelah itu dilakukan follow up bagi guru, khususnya guru Pendidikan agama Islam dalam memperbaiki penampilan pengajarannya.

Tujuan dari supervisi klinis bukan untuk men-judge baik atau burukya seorang guru melainkan memberikan pengarahan, pembinaan, atau bimbingan secara khusus dalam meningkatkan profesionalitas penampilan mengajarnya.

\section{3) Supervisi kolegial atau kesejawatan}

Supervisi kolegial merupakan proses pemberian layanan supervisi yang dilakukan secara kelompok antar guru yang satu dengan guru yang lainnya. Seperti saling bekerja sama, memberikan dorongan, ataupun bimbingan. Supervisi kelompok bertujuan memecahkan satu masalah/persoalan yang dihadapi oleh beberapa orang, sesuai dengan kemampuan dan keahliannya masing-masing. 
Banyaknya permasalahan yang diselesaikan hanya berdasarkan pada pandangan supervisor ataupun guru yang bersangkutan saja sehingga membuat supervisi individual dianggap kurang efektif.

Dalam pelaksanaanya, supervisi kolegial bisa diaplikasikan dengan cara membentuk kelompok-kelompok kerja yang meliputi kelompok kerja guru, kepala sekolah, penilik, dan juga pusat kerja guru.

Selain itu, dapat pula dilakukan musyawarah antar guru mata pelajaran, penataran, workshop, dan kunjungan antar kelas.

Musyawarah antar guru mata pelajaran bertujuan umntuk memecahkan problematika yang dialami guru dalam proses pembelajaran dengan berbagai kegiatan seperti pertemuan diskusi, pengajaran contoh, demonstrasi penggunaan ataupun pembuatan media belajar. Dalam hal ini guruguru PAI yang ada di satu sekolah bekerja sama untuk memecahkan berbagai masalah yang dihadapi dan meningkatkan kualitas dirinya.

Penataran ataupun workshop adalah salah satu cara pembinaan secara langsung kepada guru dengan melakukan kegiatan-kegiatan sebagai tindak lanjut dari permasalahan yang sering dihadapi oleh guru dalam proses pembelajaran. Kegiatan-kegiatan yang dilakukan sebisa mungkin dapat memberikan solusi dan motivasi bagi para guru PAI agar menerapkannya pada pembelajaran nantinya.

Kunjungan antar kelas merupakan kegiatan saling mengunjungi antar kelas untuk menambah pengalaman dalam proses pembelajaran guru, termasuk dalam pengelolaan kelas, pengembangan metode-metode mengajar dan sebagainya. Kunjungan antar kelas ini bukan saja dilakukan oleh guru PAI tetapi juga guru yang lain sehingga dapat mempererat hubungan silaturahmi antar guru.

Dengan demikian, pola supervisi pendidikan PAI terbagi atas supervisi pendidikan/umum, supervisi klinis atau PBM, dan supervisi kolegial/kelompok.

\section{b. Prinsip-prinsip supervisi}

Mengenai prinsip-prinsip dari supervisi, kita dapat merujuk pada beberapa pendapat yang ada. Menurut Gunawan, prinsip supervisi terbagi atas :1

1) Prinsip fundamental/dasar

2) Prinsip praktis

Prinsip fundamental/dasar artinya setiap pemikiran, sikap, dan tingkah laku seorang supervisor harus berdasar/berlandaskan pada sesuatu yang kuat/kokoh, sehingga tidak mudah berubah-ubah dan dapat dipertanggungjawabkan.

Sementara prinsip praktis yaitu prinsip dimana seorang supervisor melaksanakan kegiatan supervisi dengan melihat situasi dan keadaan di sekolah tersebut. Supervisor diharapkan agar tidak mempersulit guru, menghargai proses dan tidak terlalu terburu-buru mengharapkan hasil apalagi sampai mendesak orang yang disupervisi.

\footnotetext{
${ }^{1}$ Ary H. Gunawan, Administrasi Sekolah, (Jakarta: Rineka Cipta, 2002), h. 196
} 
Selain prinsip-prinsip tersebut, Sahertian mengemukakan beberapa prinsip supervise yang harus dilaksanakan yaitu :2

1) Prinsip ilmiah (scientific)

2) Prinsip demokratis

3) Prinsip kerjasama

4) Prinsip konstruktif dan kreatif

Prinsip ilmiah yaitu prinsip yang dilakukan berdasarkan data yang bersifat objektif yang diperoleh sesuai fakta yang terjadi pada pelaksanaan proses pembelajaran. Untuk itu diperlukan media yang dapat merekam data agar hasil yang didapatkan lebih akurat. Prinsip ini harus dilakukan dengan tersencana, sesuai sistem dan continue (berkelanjutan).

Prinsip demokratis yaitu prinsip yang didalamnya mengandung makna saling menghargai dan menjunjung tinggi martabat guru, tidak mengenal istilah atasan dan bawahan, tetapi hubungan kolegial atau kesejawatan.

Prinsip kerjasama dalam hal ini ialah mengembangkan usaha bersama-sama, yang didalamnya terdapat kegiatan sharing pengalaman ataupun ide-ide dan saling support (mendukung), serta memberikan stimulasi guru sehingga rasa kebersamaan akan muncul dalam dirinya.

Prinsip kontruktif dan kreatif yaitu prinsip yang di dalamnya guru merasa senang dengan supervisi yang dilakukan. Guru akan merasa terdorong untuk mengembangkan potensi dan kreatifitasnya apabila kegiatan supervisi tersebut mampu menciptakan suasana kerja yang nyaman, fun dan tidak menakutkan.

Oteng Sutisna (1983) mengemukakan ada beberapa prinsip utama mengenai supervisi, yaitu:3

1) Kegiatan supervisi disesuaikan dengan situasi dan kondisi, agar dapat memenuhi apa yang menjadi kebutuhan perseorangan dari pihak sekolah yang disupervisi.

2) Pada hakikatnya bantuan supervisi merupakan suatu kebutuhan karena merupakan hak para pelaksana pendidikan di sekolah.

3) Hendaknya supervisi memaparkan secara jelas mengenai tujuan dan sasaran pendidikan.

4) Hendaknya supervisi merupakan bantuan dan pembinaan untuk guru dan bagian sekolah..

5) Hendaknya supervisi adalah sarana untuk menguraikan tentang hasil penelitian pendidikan yang ter-update dan mendiskusikannya .

Dengan demikian, dapat disimpulkan bahwa prinsip-prinsip supervisi berdasarkan pendapatpendapat tersebut adalah sebagai berikut :

1) Supervisi dijalankan berdasarkan pada sesuatu yang kokoh dan praktis

2) Supervisi dilakukan sesuai dengan data diperoleh sesuai fakta yang terjadi pada pelaksanaan proses pembelajaran

3) Supervisi dilakukan secara profesional dan bukan berdasarkan hubungan pribadi atau pun hubungan kekerabatan lainnya, dan tidak memaksakan kehendak, menghargai usaha serta saling menghargai dan menjunjung tinggi martabat guru.

4) Supervisi dilaksanakan dengan menjalin hubungan yang baik antar guru dan yang lainnya.

${ }^{2}$ Piet A. Sahertian, Konsep Dasar dan Teknik Supervisi Pendidikan, (Jakarta: Rineka Cipta, 2008),

${ }^{3}$ Suharsimi Arikunto, Dasar-Dasar Supervisi, (Rineka Cipta, Jakarta: 2004), hal. 22-2 
5) Supervisi harusnya bersifat konstruktif dan kreatif sehingga guru akan termotivasi dan merasa senang dengan kegiatan supervisi.

\section{c. Tugas Pengawas Supervisi PAI}

Tugas utama pengawas sekolah tidak terlepas dari penilaian dan pembinaan kepada guru ataupun kepala sekolah. Pembinaan tersebut dilaksanakan berdasarkan pada pola ataupun prinsipprinsip supervise itu sendiri.

Adapun jenis-jenis tugas pengawas supervisi pendidikan menurut Ngalim Puirwanto secara tinci diuraikan sebagai berikut:

1) Menghadiri rapat/ pertemuan-pertemuan organisasi-organisasi professional.

2) Melakukan diskusi dengan guru-guru yang berkaitan dengan sasaran dan filisofi pendidikan

3) Mengadakan rapat kelompok yang membicarakan masalah yang sifatnya umum

4) Mengadakan pertemuan dengan guru secara individu yang membahas berbagai masalah yang dihadapi

5) Mengadakan diskusi mengenai metode pembelajaran.

6) Bekerjasama dan mengorganisasikan dengan kelompok guru-guru dalam program revisi kurikulum.

7) Melakukan wawancara dengan wali peserta didik berkaitan dengan pendidikan yang dianggap perlu.

8) Merencanakan demonstrasi dalam penyajian materi ajar dan sebagainya oleh guru yang ahli dalam supervisi itu sendiri, dan ahli-ahli lain dalam hal menunjukkan metode dan media pembelajaran yang baru. ${ }^{4}$

Dalam hal ini supervisi PAI (Pendidikan Agama Islam), dilakukan oleh pengawas supervisi pendidikan agama yang telah ditunjuk dari Departemen Agama, sesuai yang tercantum dalam Permenag RI No. 16 Tahun 2010 tentang Pengelolaan Pendidikan Agama pada sekolah, bagian kedua tentang pengawas pada pasal 18 .

Mengawasi jalannya pelaksanaan pendidikan agana islam di sekolah-sekolah merupakan tugas utama dari Pengawas Pendidikan PAI . Tugas tersebut meliputi menilai, membina, memantau, meneliti, melaporkan, dan memberi follow up dalam rangka meningkatkan mutu pelaksanaan pendidikan agama. .

Selain supervisor yang ditunjuk tersebut, supervisi juga dapat dilakukan oleh kepala sekolah karena kepala sekolah merupakan orang yang membawahi guru yang ikut bertanggungjawab memberikan bimbingan dalam meningkatkan kinerja guru-guru yang dibawahinya.

Dengan demikian dapat disimpulkan bahwa tugas pengawas supervisi PAI selain menghadiri rapat/pertemuan dengan guru-guru PAI, mendiskusikan masalah dan metode-metode mengajar guru khususnya dalam PAI, juga memberikan pembinaan, penelitian, memberikan pelatihan, memberikan rekomendasi, mengevaluasi, memberikan masukan dan laporan-laporan hasil supervisi serta memberikan penilaian.

\section{Penutup}

a. Pola supervisi PAI terbagi atas supervisi pendidikan/umum, supervisi klinis atau PBM, dan supervisi kolegial/kelompok.

\footnotetext{
${ }^{4}$ Ngalim Purwanto, Administrasi dan Supervisi Pendidikan, (Jakarta: PT.Rosdakarya, 2008), h.88
} 
b. Prinsip-prinsip supervisi PAI yaitu:

1) Supervisi dijalankan berdasarkan pada sesuatu yang kokoh dan praktis

2) Supervisi dilakukan sesuai dengan data diperoleh sesuai fakta yang terjadi pada pelaksanaan proses pembelajaran

3) Supervisi dilakukan secara profesional dan bukan berdasarkan hubungan pribadi atau pun hubungan kekerabatan lainnya, dan tidak memaksakan kehendak, menghargai usaha serta saling menghargai dan menjunjung tinggi martabat guru.

4) Supervisi dilaksanakan dengan menjalin hubungan yang baik antar guru dan yang lainnya.

5) Supervisi harusnya bersifat konstruktif dan kreatif sehingga guru akan termotivasi dan merasa senang dengan kegiatan supervisi.

c. Tugas pengawas supervisi PAI yaitu menghadiri rapat/pertemuan dengan guru-guru PAI, mendiskusikan masalah dan metode-metode mengajar guru khususnya dalam PAI, juga memberikan pembinaan, penelitian, memberikan pelatihan, memberikan rekomendasi, mengevaluasi, memberikan masukan dan laporan-laporan hasil supervisi serta memberikan penilaian. 


\section{DAFTAR PUSTAKA}

Ali,Mohammad Daud.2000.Pendidikan Agama Islam.Jakarta: PT. Raja Grafindo Persada Grafindo Persada

Ametembun, N.A.2007. Supervisi Pendidikan Disusun Secara Berprogam.Bandung: Suri

Arikunto,Suharsimi.2004.Dasar-Dasar Supervisi.Jakarta:Rineka Cipta

Departemen Agama RI. 2010. Peraturan Menteri Agama RI Tentang Pengelolaan Pendidikan Agama Pada Sekolah. Jakarta : KEMENAG RI

Gunawan,Ary H.2002.Administrasi Sekolah.Jakarta : Rineka Cipta

Maryono. 2011.Dasar-Dasar \& Teknik Menjadi Supervisor Pendidikan, Yogyakarta : Ar-Ruzz Media

Muslim,Sri Banun.2010.Supervisi Pendidikan Meningkatkan Kualitas Profesionalisme Guru. Bandung: CV. Alfabeta

Ngalim Purwanto.2008.Administrasi dan Supervisi Pendidikan.Jakarta : PT. Rosdakarya

Sahertian,Piet A.2008.Konsep Dasar dan teknik Supervisi Pendidikan.Jakarta: Rineka Cipta

Sudrajat,Ahmad.Tugas Pokok Dan Fungsi Pengawas Sekolah.(online). (http://akhmadsudrajat.wordpress.com/2008/04/08/tugas-pokok-fungsi-hak-dan-wewenangpengawas-sekolahsatuan-pendidikan//, diakses tanggal 15 Maret 2013) 